\title{
Characterization of Solanum surattense Burm. f Fruit through Chromatographic, Chemical and Analytical Methods
}

\author{
Achintya Kumar Mandal, Meenatchisundaram Saravanan, Subramanian Subashini, Sujith Thatipelli, Rajesh Allu, Ramachandran Shakila* \\ Siddha Central Research Institute (Central Council for Research in Siddha, Ministry of AYUSH, Government of India) Anna Hospital Campus, Arumbakkam, Chennai, \\ Tamil Nadu, INDIA.
}

\begin{abstract}
Background: Solanum surattense Burm.f. is an important medicinal plant in Indian traditional medicinal systems. Fruits of the plant are used for curing asthma, fever, gonorrhoea, respiratory disease and rheumatism. The aim of the study is to investigate the physicochemical, chromatographic analysis and spectral characterization of fruits of $S$. surattense Burm.f. Methods: Fruit powder was subjected to loss on drying, total ash, water soluble ash, acid insoluble ash, water soluble extractive, alcohol soluble extractive and $\mathrm{pH}$, High performance thin layer chromatography (HPTLC), High pressure liquid chromatography (HPLC) studies were carried out for identifying the active phyto constituents. Minerals of $S$. surattense in the form of ash was analysed for exploring the elements through instrumental characterization such as X-ray Fluorescence (XRF), Energy Dispersive X-Ray analysis (EDAX), X-Ray Photoelectron Spectroscopy (XPS), Powder X-Ray Diffractometer (PXRD) and Inductively Coupled Plasma Optical Emission Spectroscopy (ICP-OES). Results: In HPTLC photo documentation under $254 \mathrm{~nm}, 366 \mathrm{~nm}$ and after derivatization with vanillin sulphuric acid reagent
\end{abstract}

observed six, nine and six spots respectively. HPLC chromatogram at 235 $\mathrm{nm}$ showed separation of eleven peaks. In the characterization techniques, carbon, oxygen, magnesium, silicon, sulphur, phosphorous, sodium, potassium, chlorine, calcium were the elements identified. Conclusion: The study pay way to quality control parameters as well as mineral value of the plant.

Key words: Solanum surattense, Kantakari, Respiratory troubles, Chromatography, Elemental analysis.

Correspondence

Dr. R Shakila,

Research Officer (Chemistry), Siddha Central Research Institute, Arumbakkam, Chennai-600106, Tamil Nadu, INDIA.

Email id: r.shakila@gov.in

DOI: 10.5530/jyp.2021.13.91

\section{INTRODUCTION}

Plants are rich source of all elements essential for human and animal. Every constituent plays an important role and deficiency of any constituent may lead to abnormal growth in the body. Thus, qualitative and quantitative determination of mineral elements present in plants is a primary task.

Solanum surattense is an important medicinal plant in Indian traditional medicine systems. It is commonly known as a kantakari in Sanskrit and the Indian night shade or yellow berried nightshade in English. Solanum surattense Burm. $\mathrm{f}$. is a perennial herbaceous weed belongs to Solanaceae family. It is distributed throughout the tropical regions of India. Traditionally it is used for treating asthma, cough, leprosy, dropsy, sore throat and constipation, dysuria. ${ }^{1,2}$ In Siddha system of Medicine various parts of the plants of $S$. surattense are used in preparation of various drugs viz., Vata curak kutinir, kakkuvan ilakam, cara punka vilvati ilakam, kakkana mattirai, parangipattai iracayanam and tutuvalai nei for treatment of various diseases like fever, shivering fever, whooping cough etc. ${ }^{3}$ Phytochemically the plant is enriched with polyphenols, sterols, flavonoids, saponins ${ }^{4}$ and alkaloid. ${ }^{5}$ Eleven saponins of which one new avenacoside-type saponin, two new steroidal saponins, one revised-structure steroidal saponin and six known torvoside $\mathrm{K}$, torvoside $\mathrm{J}$, torvoside $\mathrm{L}$, khasianine, aculeatiside $\mathrm{A}$ and solamargine has been reported from arial part of the plant. ${ }^{6}$ Pharmacologically the plant shows numerous potent activities. The leaf extract of S. surattense showed potent antibacterial effects against Staphylococcus aureus, Streptococcus sp.; Bacillus subtilis, Escherichia coli, Pseudomonas aeruginosa, Salmonella typhii, Shigella dysenteriae and Vibrio cholera. ${ }^{7}$ Leaf extract of this plant markedly reduced dyslipidemia and hyperglycemia in STZ-induced diabetic rats. ${ }^{8}$ Leaf of S. surattense demonstrated its promising in vitro and in vivo anti-oxidative, anti-apoptotic and hepatoprotective potential against chemical-induced liver damage. ${ }^{4}$ Investigations of alcoholic extracts of $S$. surattense leaf leads to the exhibition of significant antiulcer property. ${ }^{9}$ The study of $S$. surattense seed extract on the oxidative potential of the cauda epididymal spermatozoa in albino male rats shows a decreased oxidative potential indicating the antifertility effect. ${ }^{10}$ Seed fumes of this plant are useful in the treatment of tooth pain, gum and swellings. It is also found to relieve fever, rheumatism, pneumonia and other respiratory troubles ${ }^{11}$ seed powder of $S$. surattense can be used for relieving pulpal pain. ${ }^{12}$ Aqueous methanolic extract of $S$. surattense fruit exhibits substantial diuresis that validated its folkloric use in dysuria. ${ }^{2}$ Similar findings are noticed on the anthelmintic efficiency of $S$. surattense fruit ethanolic and aqueous extracts. ${ }^{13}$ This plant has been reported for antimalarial activity also. ${ }^{14}$

\section{MATERIALS AND METHODS}

\section{Plant Collection}

Fruits of S. surattense (SSF) were collected from natural habitats in Mettur region of Salem District, Tamil Nadu and authenticated by Research Officer (Pharmacognosy) of our Institute.

\section{Sample Preparation}

Fruits were dried at room temperature and coarsely powdered. The powdered sample was taken for physico-chemical analysis. The coarse powder was taken in silica dish and kept in muffle furnace maintained at $600^{\circ} \mathrm{C}$ till ash became carbon free. Then it was cooled in desiccator, 
stored in air tight container and labelled as SSF for further analysis and chemical characterization. For HPTLC and HPLC analysis, $2 \mathrm{~g}$ of plant material was sonicated with $20 \mathrm{ml}$ of methanol for $30 \mathrm{~min}$. It was filtered and filtrate was taken in sample vial for further analysis. For ICP-OES analysis, $0.5 \mathrm{~g}$ sample was accurately weighed and taken with $10 \mathrm{ml}$ con. $\mathrm{HCl}$ and $10 \mathrm{ml}$ con. $\mathrm{HNO}_{3}$. Then the solution was kept on laboratory microwave digester. Further $10 \mathrm{ml}$ of con. $\mathrm{HCl}$ was added to it for complete digestion. Finally, the solution filtered through Whatman no.1 filter paper. The filtrate solution was made-up to $250 \mathrm{ml}$ in a standard measuring flask. The solution was taken for instrumental analysis.

\section{Chemicals and Solvents}

Analytical grade solvents methanol, toluene, ethyl acetate, and formic acid, conc. $\mathrm{HCl}$, conc. $\mathrm{HNO}_{3}$ and $\mathrm{HPLC}$ grade methanol were purchased from Merck. Vanillin (1 g) sulphuric acid in methanol (5\%) solution (VSR) was used for visualisation for HPTLC analysis.

\section{Physicochemical analysis}

Powdered SSF was undergone for loss on drying, extractive values, total ash, water soluble ash, acid insoluble ash and $\mathrm{pH}$ analysis according to the standard methods. ${ }^{15}$

\section{Characterization Techniques}

Chromatographic analysis was performed using High Performance Thin Layer Chromatography (HPTLC) and High Pressure Liquid Chromatography (HPLC). Surface morphology, elemental composition and mapping were obtained by field emission scanning electron microscopy (FE-SEM) attached to dispersive X-ray spectrometry (EDX) and X-Ray Photoelectron Spectroscopy (XPS). The mineral composition was determined using X-Ray fluorescence spectrometer (XRF), powder $\mathrm{X}$-ray diffractometer (PXRD) and inductively coupled plasma optical emission spectrometer (ICP-OES).

High-performance thin layer chromatography (HPTLC) analysis: HPTLC analysis was performed by CAMAG HPTLC instrument (Switzerland). Ten micro litre of sample solution was applied on silica gel $60 \mathrm{~F}_{254}$ coated aluminium plate $(4 \times 10 \mathrm{~cm})$ as $8 \mathrm{~mm}$ band length and $10 \mathrm{~mm}$ distance from bottom by Autosampler ATS4. Plate was developed using toluene: ethyl acetate: formic acid $(5: 2: 0.5, v / v / v)$ in presaturated twin trough chamber $(10 \times 10 \mathrm{~cm})$. The developed plate was dried over hot plate and photograph was taken in CAMAG Visualizer Chamber followed by scanning under $\lambda_{254}$ (absorbance mode, D2 lamp) and $\lambda_{366}$ (Fluorescence mode, $\mathrm{Hg}$ lamp) respectively with a slit dimension $6 \times 0.45$ $\mathrm{mm}$ and scanning speed of $20 \mathrm{~mm} / \mathrm{s}$ by scanner 4 (Scanner_210441) linked with WINCATS software. The scanned plate was dipped in VSR and heated at $105^{\circ} \mathrm{C}$ till the appearance of colored bands. Photograph was taken immediately at white light followed by scanning at $\lambda 520$ at absorption mode (W lamp).

High-performance liquid chromatography (HPLC) analysis: HPLC experiments were performed by a Shimadzu LC-20AP (Shimadzu Corporation, Kyoto, Japan, Lab Solution Software, version 5.92.). The system was equipped with degassing unit, column oven, LC-20AP quaternary low pressure mixing pump, Shimadzu SPD-M20A UVVISIBLE detector with thermo stated flow cell. A shim pack RP-C column ( 150 X $4.6 \mathrm{~mm} ; 3 \mu)$ and $20 \mu \mathrm{L}$ Hamilton injector were used for the analysis. The UV spectra were recorded using Shimadzu spectrometer.

SEM-EDX: Field emission scanning electron microscope (FESEM, TESCAN-MIRA 3XMU, Czech Republic) was used for the present study. The material was mounted directly on stubs using double-side adhesive tape and sputtered with a thin layer of gold in a Fine Coater. The electron micrographs were obtained at $15 \mathrm{kV}$, with an integrated digital image acquisition system.
The elemental analyses were obtained by an energy dispersive spectrometer (EDS, TESCAN-MIRA 3XMU, Czech Republic). The Instrumental parameters for FBGLA, fixed as Voltage was $10 \mathrm{kV}$, magnitude was 386, take off was $3 \mathrm{~s}$ and live time was $81.9 \mathrm{~s}$, amplitude time was 3.84 sand resolution was $27.4 \mathrm{eV}$; for FBYLA sample the set magnitude was 570 .

XRF: The measurements were performed XGT-2700 X-ray analytical microscope (Horiba, Japan) with X-ray tube and an Rh-anode. The tube voltage and current were $50 \mathrm{kV}$ and $1 \mathrm{~mA}$, respectively. High purity silicon detector (XEROPHY) capable of detecting sodium to uranium (Atomic numbers 11 to 92) was used. Range of CCD camera was magnification 30 and 100 approximately which can analyse varied type of samples like Metal plates, powders and coatings. Instrumentation parameters were fixed. Live time was $60 \mathrm{~s}$, processing time was $\mathrm{P} 3, \mathrm{XGT}$ diameter is 10 $\mu \mathrm{m}$; X-ray tube voltage was $50 \mathrm{kV}$, current was $1.000 \mathrm{~mA}$, X-ray filter and cell were nonexistence and quantification correlation were standard-less.

PXRD: Powder diffraction data were collected by Aeris PANalytical Diffractometer with Ni-filtered copper radiation, in Bragg-Brentano geometry with the sample prepared in thin layer on a silicon zerobackground holder. $1 \mathrm{~g}$ of FBG, FBY was taken and powdered in Agate mortar to very fine powder. PXRD patterns were scanned in the range $2 \theta=10-100^{\circ}$ with a step size of $0.01^{\circ}$ and $40 \mathrm{~s} / \mathrm{step}$. The PANalytical High Score Plus software suite was used for data treatment.

XPS: Samples for XPS analyses were prepared by attaching a very thin layer of freshly prepared powder to an adhesive tape placed on a sample holder. The XPS studies were carried out with a Perkin- Elmer PHI 5500 ESCA System, using monochromatic aluminium KR (E)1486.6 eV) radiation. An instrument vacuum of at least 10-9 Torr was maintained for all the analyses. The instrument was calibrated for Au4f7/2 peak binding energy of $84.0 \mathrm{eV}$. All spectra were acquired with a resolution of $0.5 \mathrm{eV}$. The binding energies for the XPS spectra were referenced to the hydrocarbon component of the C1s spectrum at $285.0 \mathrm{eV}$. The XPS spectra were fit by using Gaussian-Lorentzian peak shapes, and Shirley's baseline correction function was subtracted.

ICP-OES: In this study, the wet digestion of the samples was performed using a laboratory microwave digester with 40 closed vessels (Mars 6, CEM, USA). An inductively coupled plasma optical emission spectrometer (Agilent, Model 720 series, Santa Clara, California, USA) was used for the determination of elements present in the samples FBGLA and FBYLA. The gas employed was argon with $99.99 \%$ purity. For sample preparation, the method of EPA 3050B was followed.

\section{RESULTS}

The physico-chemical value of $S$. surattense is presented in Table 1. TLC photo-documentation of methanol extract of the plant sample (Figure 1) revealed six spots with $\mathrm{R} f 0.05,0.13,0.24,0.28,0.39$ and 0.64 (all are green) under short UV. Under long UV 9 bands were observed with $\mathrm{R} f$ 0.05 (blue), 0.08 (red), 0.20 (blue), 0.28 (fluorescent blue), 0.36 (blue), 0.54 (green), 0.61 (green), 0.64 (red) and 0.68 (red). Post derivatized plate divulged six bands with $\mathrm{R} f 0.08,0.17,0.25,0.29,0.59$ and 0.65 (all were violet) under white light. Densitometric scan of methanol extract of S. surattense fruit showed 9 peaks with $\mathrm{R} f 0.27$ (area $40.21 \%$ ), 0.63 (area $23.26 \%$ ) and 0.38 (area $9.69 \%$ ) as prominent under short UV. Scanning under long UV revealed 8 peaks with $\mathrm{R} f 0.26$ (area $53.41 \%$ ), 0.28 (area $19.59 \%$ ) and 0.59 (area 16.53\%) as major. For post derivatized plate, 11 peaks came out with $\mathrm{R} f 0.63$ (area $27.53 \%$ ), 0.56 (area $24.65 \%$ ) and 0.06 (area $17.59 \%$ ) as leading under white light scanning (Figure 1, Table 2A).

For HPLC Analysis of sample S. surattense fruit appeared with eleven peaks with retention time 8.016 (area $11341137 \mathrm{mAU}), 8.672$ (3903666 mAU), 9.498 (4334488 mAU), 10.626 (16435603 mAU), 11.270 (1923486 
Table 1: Physico-chemical results of SSF.

\begin{tabular}{cc}
\hline Parameters & Mean value \pm SD $(\mathbf{n}=\mathbf{2})$ \\
\hline Loss on drying $\left(105^{\circ} \mathrm{C}\right)(\%)$ & $9.42 \pm 0.07$ \\
Total Ash (\%) & $7.57 \pm 0.02$ \\
Water soluble Ash (\%) & $5.20 \pm 0.10$ \\
Acid insoluble Ash (\%) & $0.98 \pm 0.13$ \\
Water Soluble Extractive (\%) & $8.83 \pm 0.03$ \\
Alcohol Soluble Extractive (\%) & $9.42 \pm 0.07$ \\
pH & 6.60 \\
\hline
\end{tabular}

Table 2A: $\mathbf{R}_{f}$ and colour of spots in HPTLC of SSF.

\begin{tabular}{cccccc}
\hline $\mathbf{R}_{\mathbf{f}}$ & Colour & $\mathbf{R}_{\mathbf{f}}$ & Colour & $\mathbf{R}_{\mathbf{f}}$ & Colour \\
\hline 0.05 & Green & 0.05 & Blue & 0.08 & Violet \\
0.13 & Green & 0.08 & Red & 0.17 & Violet \\
0.24 & Green & 0.20 & Blue & 0.25 & Violet \\
0.28 & Green & 0.28 & F. blue & 0.29 & Violet \\
0.39 & Green & 0.36 & Blue & 0.59 & Violet \\
0.64 & Green & 0.54 & Green & 0.65 & Violet \\
- & - & 0.61 & Green & - & - \\
- & - & 0.64 & Red & - & - \\
- & - & 0.68 & Red & - & - \\
\hline
\end{tabular}

Table 2B: $\mathbf{R}_{t}$ and peak area in HPLC of SSF.

\begin{tabular}{cccc}
\hline Peak & Ret. Time & Area mAU & Area \% \\
\hline 1 & 8.016 & 11341137 & 29.800 \\
2 & 8.672 & 3903666 & 10.257 \\
3 & 9.498 & 4334488 & 11.389 \\
4 & 10.626 & 16435603 & 43.186 \\
5 & 11.270 & 1923486 & 5.054 \\
6 & 14.019 & 15196 & 0.040 \\
7 & 14.244 & 92908 & 0.244 \\
8 & 15.910 & 1809 & 0.005 \\
9 & 16.696 & 1722 & 0.005 \\
10 & 18.271 & 2136 & 0.006 \\
11 & 19.044 & 5667 & 0.015 \\
Total & 38057820 & & 100.000 \\
\hline
\end{tabular}

mAU), 14.019 (area $15196 \mathrm{mAU}), 14.244$ (92908 mAU), 15.910 (1809 $\mathrm{mAU}), 16.696$ (1722 mAU), 18.271 (2136 mAU) and 19.044 (5667 mAU) under wavelength $\lambda 235$. HPLC analysis result is shown in Figure 2 and Table 2B.

SEM images a sample by scanning it with a high-energy beam of electrons. The electrons interact with the atoms that frame the sample producing signals that contain information about the sample's surface topography, composition. The morphology of SS was observed by FE-SEM and shown in Figure 3A. The images are of non-crystalline amorphous structure.

EDX analysis of SSF confirmed the presence of $\mathrm{C}, \mathrm{O}, \mathrm{Mg}, \mathrm{Si}, \mathrm{P}, \mathrm{S}, \mathrm{Cl}$, $\mathrm{K}$ and $\mathrm{Ca}$. $\mathrm{C}, \mathrm{O}$ and $\mathrm{K}$ are present as major constituents. $\mathrm{Cl}$ is present in moderate amount. Remaining elements are in trace amount. $\mathrm{CaCO}_{3}$, $\mathrm{SiO}_{2}, \mathrm{MgO}, \mathrm{GaP}, \mathrm{FeS}_{2}, \mathrm{KCl}, \mathrm{MAD}-10$ Feldspar and Wollastonite were

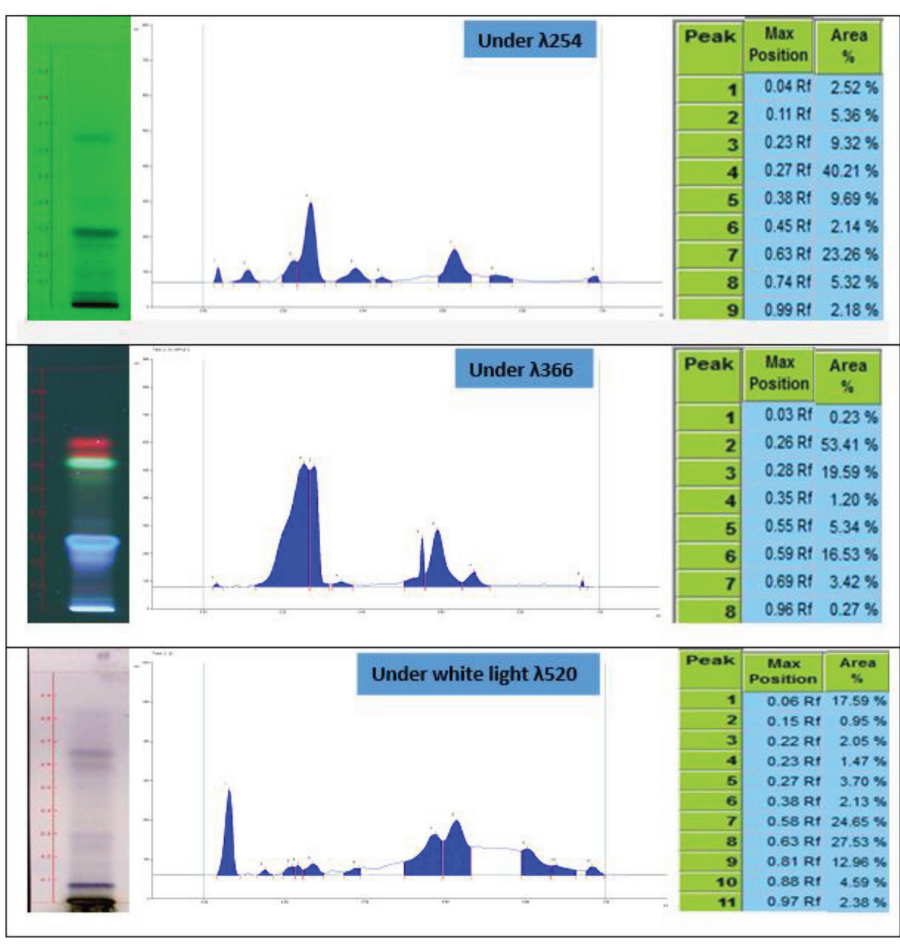

Figure 1: HPTLC chromatogram with fingerprint profile of SSF.

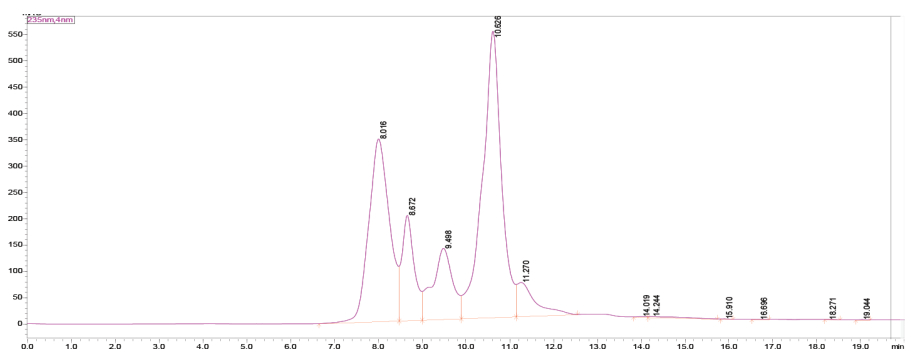

Figure 2: HPLC Chromatogram at $\lambda 235$.

used as standards. Analysis image is shown in Figure 3B and elemental mapping in Figure 3C-3F; values are presented in Table 3A.

$\mathrm{X}$-ray fluorescence spectroscopy (XRF) was done for quantitative analysis of multi elements present in fruits of Solanum surattense. Presence of Sodium, potassium, calcium, chlorine, and phosphorous were quantified as $46.03 \%, 39.37 \%, 10.87 \%, 2.38 \%$ and $1.35 \%$ (mass percentage) respectively. The number of elements and its amount have been enlisted in Table 3B and Figure 3G.

The analysed peaks of the SSF were matched with the standard data available in International Centre for Diffraction Data (ICSD). Peaks of 2 Theta angles 28.31 and 40.48 showed higher intensities. Some other intermediate and small peaks were observed at $2 \theta$ angles of 27.92, 29.69, $30.27,30.85,32.22,33.18,33.84,43.28,50.13,66.37$ and 73.69 in low intensities. PXRD results show the presence of elements $\mathrm{K} \& \mathrm{Cl}$ in the form of sylvine (KCl-98-024-0503), $\mathrm{SiO}_{2}$ amorphous (98-015-5242) and dolomite ( $\left.\mathrm{CaMgC}_{2} \mathrm{O}_{6}-98-017-1524\right)$. PXRD analysis graph has been enlisted in Figure $3 \mathrm{H}$.

Earlier XRF, EDX analysis indicate the presence of macrominerals and microminerals. XRD analysis predicts phase identification and chemical composition of the element. It confirms the minerals present in surfaces 


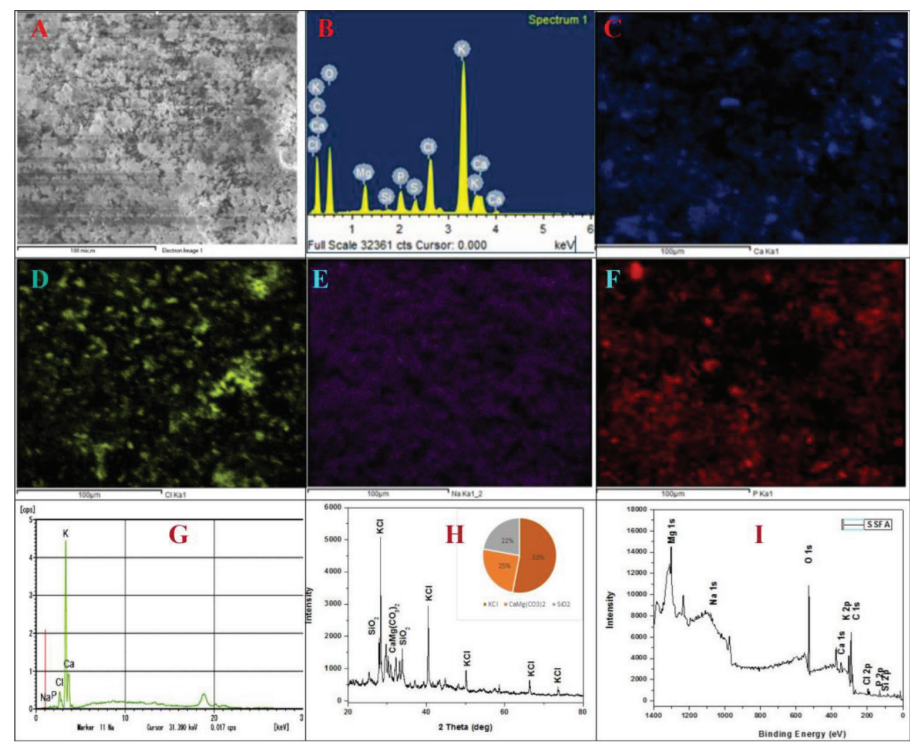

Figure 3: A. SEM image of SSFA; B. EDX graph of SSFA. C,D,E,F. EDX elemental mapping for $\mathrm{Ca}, \mathrm{Cl}, \mathrm{Na}$ and $\mathrm{P} ; \mathrm{G}$. XRF graph of SSFA; $\mathrm{H}$. PXRD pattern of SSFA; I. XPS graph of SSFA.

Table 3A: EDX result of SSFA.

\begin{tabular}{ccc}
\hline S.No & Elements & Weight \% \\
\hline 1 & Carbon & 32.13 \\
2 & Oxygen & 37.44 \\
3 & Magnesium & 2.24 \\
4 & Silicon & 0.12 \\
5 & Phosphorous & 1.75 \\
6 & Sulphur & 1.00 \\
7 & Chlorine & 5.23 \\
8 & Potassium & 17.81 \\
9 & Calcium & 2.28 \\
\hline
\end{tabular}

Table 3B: XRF result of SSFA.

\begin{tabular}{ccc}
\hline S.No & Elements & Weight \% \\
1 & Sodium (Na) & 46.03 \\
2 & Phosphorous (P) & 1.35 \\
3 & Chlorine $(\mathrm{Cl})$ & 2.38 \\
4 & Potassium (K) & 39.37 \\
5 & Calcium (Ca) & 10.87 \\
\hline
\end{tabular}

with their electronic configuration. XPS data of sample SSF identified the presence of elements $\mathrm{C}, \mathrm{O}, \mathrm{P}, \mathrm{K}, \mathrm{Mg}, \mathrm{Na}, \mathrm{Ca}, \mathrm{Si}$ and $\mathrm{Cl}$ with their corresponding various chemical states. XPS result is shown in Figure 3I and Table $4 \mathrm{~A}$.

The ICP-OES results showed the presence of calcium, potassium, magnesium, sodium and phosphorous. The results are shown in Table 4B.

\section{DISCUSSION}

Loss on drying denotes the weight loss due to hygroscopic moisture and volatile substances. The LOD value was found to be $9.42 \%$.
Table 4A: XPS data of SSFA.

\begin{tabular}{cccc}
\hline S.No & Elements & Electronic state & Binding Energy $(\mathrm{eV})$ \\
\hline 1 & $\mathrm{C}$ & $1 \mathrm{~s}$ & 290.0 \\
2 & $\mathrm{O}$ & $1 \mathrm{~s}$ & 528.0 \\
3 & $\mathrm{P}$ & $2 \mathrm{p}$ & 130.0 \\
4 & $\mathrm{~K}$ & $2 \mathrm{p}$ & 291.0 \\
5 & $\mathrm{Mg}$ & $1 \mathrm{~s}$ & 1301.0 \\
6 & $\mathrm{Na}$ & $1 \mathrm{~s}$ & 1070.0 \\
7 & $\mathrm{Ca}$ & $2 \mathrm{p}$ & 348.0 \\
8 & $\mathrm{Si}$ & $2 \mathrm{p}$ & 106.0 \\
9 & $\mathrm{Cl}$ & $2 \mathrm{p}$ & 196.0 \\
\hline
\end{tabular}

Table 4B: ICE-OES data of SSFA.

\begin{tabular}{ccc}
\hline S.No. & Test Parameters & Results (\%) \\
\hline 1 & Calcium & 2.22 \\
2 & Potassium & 1.64 \\
3 & Magnesium & 2.51 \\
4 & Sodium & 0.01 \\
5 & Phosphorous & 0.011 \\
\hline
\end{tabular}

Determination of ash content is necessary for quality control of the herbal drug in the powder form. The total ash contains inorganic salts either naturally present in the herbal drug or brought there by additive mode. The value was determined as $7.57 \%$. Water soluble ash value which indicates the presence of inorganic salts was found to be $5.20 \%$. Presence of internal and or external silica leads to the acid insoluble ash value of combined siliceous matter. It was calculated as $0.98 \%$. Since the plant was personally collected by following the good collection practices, the obtained value attributes to the internal siliceous matter present in the plant. Water soluble extractive and alcohol soluble extractive values were estimated as $8.83 \%$ and $4.67 \%$ which indicates the plant sample is more soluble in water than alcohol. The $\mathrm{pH}$ value was determined as 6.60 which indicates the slight acidic nature of the drug despite the presence of alkaloids which means that the dominance of other acid like phyto compounds over alkaloids. ${ }^{16}$

The EDAX, XRF, PXRD are instrumental techniques which analyses the surface elements and which give different elemental composition in different locations of the sample; ICP-OES measures the content of elements in the whole sample. ${ }^{17}$

Every micro and macro elements play an important role in human biology. Silicon plays as bioactive beneficial element. It is highly abundant in soil and occurs in all organisms including plants and humans. In plants, silicon plays an essential role in growth and development. Human beings receive silicon from plants through plant derived food products. Bioavailability of silicon in human diet, strengthens bones and improves immune response, as well as neuronal and connective tissue health. ${ }^{18}$

Sulphur is required by all living organisms. Sulphur is one of the most essential elements for human livings. Sulphur containing organic compounds include amino acids (cysteine, cystine and methionine which are components of proteins), vitamins (thiamine and biotin), the cofactor lipoic acid, certain complex lipids mucopolysaccharides (chondroitin sulphate), the sulphated polysaccharides, various low molecular-weight compounds, such as glutathione and the hormone insulin and anticoagulant heparin. ${ }^{19,20}$ Potassium is necessary for functioning of all living cells present in all plant and animal tissues. Potassium is the main intracellular ion for all types of cells having a 
major role in maintenance of fluid and electrolyte balance. ${ }^{21}$ Calcium ion is of various activities in animal biological system such as muscle contraction, microtubule formation, hormonal responses, exocytosis, fertilization, neurotransmitter release, blood clotting, protein stabilization, intercellular communication, mineralization, cell fusion, adhesion and growth. ${ }^{22}$

Magnesium is essential element in biological systems. It plays essential role in biological activity of ATP and drug binding. It is present in chlorophyll, enzymes, nucleic acids, cell membrane walls and proteins. In human health it helps to nerve conduction, hypertension, diabetes and glucose tolerance. ${ }^{23}$ Sodium plays a key role in regulation of blood volume, blood pressure, osmotic balance and maintain a constant $\mathrm{pH}$ in human body. Sodium ions are primarily found inside the nerve cells of human..$^{21}$

\section{CONCLUSION}

Chromatographic studies give an idea of presence of phytochemicals. Physicochemical and inorganic composition studies clearly states the major mineral constituents. This finding will be useful towards establishing quality control parameters for the standardisation of plant material $S$ surattense fruit. The present work predicts the potentiality of $S$ surattense fruit. Subsequently further scientific analysis is required for the development of effective remedial compounds.

\section{ACKNOWLEDGEMENT}

The authors are thankful to The Director General, Central Council for Research in Siddha and The Assistant Director I/c, Siddha Central Research in Institute for encouragement and support. CIF, CSIR-CECRI, Karaikudi, India for XRF and FESEM-EDX Facility, M/s. Gesra analytical labs, Chennai, India for ICP-OES facility.

\section{Funding}

Funded by Central Council for Research in Siddha under Intra Mural Research Scheme vide sanction no. 457/2016-17 dated 17.01.2017.

\section{CONFLICT OF INTEREST}

The authors declare that there is no conflict of interest.

\section{REFERENCES}

1. Mickymaray S, Al Aboody MS, Rath PK, Annamalai P, Nooruddin T. Screening and antibacterial efficacy of selected Indian medicinal plants. Asian Pac J Trop Biomed. 2016;6(3):185-91. doi: 10.1016/j.apjtb.2015.12.005.

2. Ahmed MM, Andleeb S, Saqib F, Hussain M, Khatun MN, Ch BA, et al. Diuretic and serum electrolyte regulation potential of aqueous methanolic extract of Solanum surattense fruit validates its folkloric use in dysuria. BMC Complement Altern Med. 2016;16:166. doi: 10.1186/s12906-016-1148-3, PMID 27255699.

3. The Siddha formulary of India. Part 1. $1^{\text {st }}$ ed. New Delhi: Department of Health,
Ministry of Health and Family Welfare, Government of India; 1979

4. Parvez MK, Al-Dosari MS, Arbab AH, Alam P, Alsaid MS, Khan AA Hepatoprotective effect of Solanum surattense leaf extract against chemicalinduced oxidative and apoptotic injury in rats. BMC Complement Altern Med. 2019;19(1):154. doi: 10.1186/s12906-019-2553-1. PMID 31269948.

5. Pawar PK, Borse TP, Pinjari RZ, Maheshwari VL. A simple technique for rapid quantitative determination of solasodine from cultured hairy roots of Solanum surattense. J Herb Toxicol. 2008;2:7-10.

6. Lu Y, Luo J, Kong L. Steroidal alkaloid saponins and steroidal saponins from Solanum surattense. Phytochemistry. 2011;72(7):668-73. doi: 10.1016/1. phytochem.2011.01.028, PMID 21334700.

7. Sheeba E. Antibacterial Activity of $<i>$ Solanum surattense $</ i>$ Burm. F Kathmandu Univ J Sci Eng Technol. 2010;6(1):1-4. doi: 10.3126/kuset.v6i1.3278.

8. Sridevi M, Kalaiarasi P, Pugalendi KV. Antihyperlipidemic activity of alcoholic leaf extract of Solanum surattense in streptozotocin-diabetic rats. Asian Pac J Trop Biomed. 2011;1(2):S276-80. doi: 10.1016/S2221-1691(11)60171-8.

9. Bahuguna Y, Juyal V, Gusain K. Pharmacological evaluation of Solanum surattense leaves for antiulcer activity. J Pharm Res. 2008;2:253-9.

10. ThirumalaiT, David E, Viviyan TS, Elumalai EK. Effect of Solanum surattense seed on the oxidative potential of cauda epididymal spermatozoa. Asian Pac J Trop Biomed. 2012;2(1):21-3. doi: 10.1016/S2221-1691(11)60183-4, PMID 23569828.

11. Pandey HP. Seed fume of Solanum surattense: A traditional panacea for teeth and gums. Indian J Tradit Knowl. 2004;3:206-7.

12. Srinivasan N VAL. Evaluating the Analgesic Efficacy of Solanum surattense (Herbal Seed Extract) in Relieving Pulpal Pain-An in-vivo Study. Dentistry. 2015;5(4):1-3. doi: 10.4172/2161-1122.1000288.

13. Barik CS, Parida N, Sahu D, Sahoo AR. Solanum surattense: Evaluation of anthelmintic activity. J Pharm Adv Res. 2018;1(5):240-6.

14. Ramazani A, Zakeri S, Sardari S, Khodakarim N, Djadidt ND. In vitro and in vivo anti-malarial activity of Boerhavia elegans and Solanum surattense. Malar J. 2010:9:124. doi: 10.1186/1475-2875-9-124, PMID 20462416.

15. Anonymous. Quality control methods for medicinal plant materials. Geneva: World Health Organization; 1998.

16. Elankani P E, Murugammal S M, Shakila R S, Pitchiahkumar M P, N. Kabilan K. Chemical Standardization of Thetran Vithai Kutinir Chooranam-An Antidiabetic Siddha Polyherbal Formulation. Pharmacogn J. 2019;11(5):1106-13. doi: 10.5530/ pj.2019.11.173.

17. Chojnacka K, Samoraj M, Tuhy Ł, Michalak I, Mironiuk M, Mikulewicz M. Using XRF and ICP-OES in biosorption studies. Molecules. 2018;23(8):2076. doi: 10.3390/molecules23082076, PMID 30126247

18. Farooq MA, Dietz KJ. Silicon as versatile player in plant and human biology: Overlooked and poorly understood. Front Plant Sci. 2015;6:994. doi: 10.3389/ fpls.2015.00994, PMID 26617630

19. Nimni ME, Han B, Cordoba F. Are we getting enough sulfur in ourdiet? Nutr Metab (Lond). 2007;4:24. doi: 10.1186/1743-7075-4-24, PMID 17986345

20. Pohl HR, Wheeler JS, Murray HE. Sodium and potassium in health and disease. Met lons Life Sci. 2013;13:29-47. https://doi: 10.1007/978-94-007-7500-8_2, doi: 10.1007/978-94-007-7500-8_2, PMID 24470088.

21. Case LP, Daristotle L, Hayek MG, Raasch MF (Eds), Chapter 6. Minerals. In: Canine and feline nutrition. $3^{\text {rd }}$ ed. Mosby; 2011:37-44. doi: 10.1016/B978-0-32306619-8.10006-4

22. Kretsinger $\mathrm{RH}$, Nelson DJ. Calcium in biological systems. Coord Chem Rev. 1976;18(1):29-124. doi: 10.1016/S0010-8545(00)82054-8

23. La Pleshchitser Ala. Biological role of magnesium. Clin Chem. 1958;4(6):429-51. doi: 10.1093/clinchem/4.6.429, PMID 13608906

Article History: Received: 21-08-2021; Revised: 04-10-2021; Accepted: 27-10-2021.

Cite this article: Mandal AK, Saravanan M, Subashini S, Thatipelli S, Allu R, Shakila R. Characterization of Solanum surattense Burm. F Fruit through Chromatographic, Chemical and Analytical Methods. J Young Pharm. 2021;13(4):370-4. 